\title{
The Role of Self-Esteem and Length of Stay on the Streets in the Development of Risky Behaviors among Adolescents
}

\author{
Oteme Apolos Christophe \\ Department of Psychology, University Félix Houphouët-Boigny, UFR / Human Sciences, Abidjan, Côte d'Ivoire
}

Email address:

otemeap@yahoo.fr

\section{To cite this article:}

Oteme Apolos Christophe. The Role of Self-Esteem and Length of Stay on the Streets in the Development of Risky Behaviors among Adolescents. American Journal of Applied Psychology. Vol. 5, No. 1, 2016, pp. 1-5. doi: 10.11648/j.ajap.20160501.11

Received: March 10, 2016; Accepted: April 25, 2016; Published: May 20, 2016

\begin{abstract}
This work aims to show how self-esteem and length of stay on the streets of adolescents of the streets affect the extent to which these adolescents behave at risk. Data were collected from 83 adolescents using a questionnaire and were analyzed using a step by step regression analysis. The results show that both self-esteem and length of stay on the streets predict risky behaviors. Specifically, high self-esteem primarily predicts low tendency to behave at risk. These results indicate that cognitive and contextual aspects play a fundamental role in juvenile social marginality. And the knowledge of these seems an interesting lead for the conception of curative as well as preventive strategies for the complex field of risky behaviors.
\end{abstract}

Keywords: Risky Behavior, Marginality, Self-Esteem, Length of Stay on the Streets

\section{Introduction}

According to Marion [1], children from the age of five (5) are brought to leave the family place of residence for more or less long periods (zero month to one year and more) and to live in the street. In addition, in the face of the intensification of their needs, these children adopt risky behaviors (e.g drug use, sexual and economic exploitation).

With regard to this situation, search for solutions is imperative. In this perspective, works have been conducted on risky behaviors among teenagers in touch with the socioeconomic and demographic situation [2], person-environment interaction [3], the membership group [4], the type of family education [5] [6].

But in spite of these efforts to find solutions, and some positive results, information is still lacking on the role of psychological causes such as the self-esteem in the development of criminal activities among street teenagers. The same is true of the role of the length of life in the street in the occurrence of risky behaviors. The present work focuses on three aspects; first, the theoretical analysis of concepts, synthesis of works and research hypotheses. Next, the methodological aspect of the study and, finally, the third part is dedicated to the results. This paper ends by the presentation of the striking facts of the study.

\section{Problem}

Teenagers' social marginality and their homelessness has become a current issue. In this regard Bellavance et al [7] observe that most part of the mortality and morbidity during the second decade of human existence is directly related to behavioral factors. It shows that the adolescence constitutes the most sensitive period of the life where the individual is the most tried by the risk-taking. It could explain the propensity of these teenagers to adopt behaviors which represent not only danger for them but also for the community. According to Lips [8], these adolescents smoke, are at risk of committing suicide, consume products and drinks alcohol. They are the most frequently infected with HIV and usually die of road accidents. [9].

Besides for certain teenagers who broke any link with their parents or family for diverse reasons, the street is the unique place of residence. That said, the street becomes a "forced choice" for this young people, who wish to find a place where they can feel socially existent [10]. They are thus faced with risks from the environment that may lead them to put themselves in danger (risky of delinquency, prostitution, physical risks) [11].

For the purposes of this study, a "street child" is identified as one who has the street as a permanent way of life, who is 
at odds with the family, and is under-18 years of age. This is different from a child in the street who is temporarily on the streets, who practices small street "jobs" and who is still in contact with family [12].

The key question that arises is: what are then the psychological and contextual factors that may induce marginality risky behaviors among adolescents of the street? Specifically, what is the role of both self-esteem and length of stay in the street in the occurrence of risky behavior, that is in the process that leads adolescents on the streets to acting out?

According to Fischoff $\&$ al. [13], risk can be defined as a potential threat more or less predictable for life and health. It can be likened to the probability of occurrence of a threat. From this perspective, Leplat [14] adopting a framework used by Otémé [8] of setting risk compared to threat, characterizes risk as the probability that a threat is updated. In other words it actually causes damage in specific conditions. "Damages", in the framework of this work, are marginality and adolescents' delinquency [15].

Studies have been devoted to risky behaviors in several areas following themes as diverse and varied: socioeconomic characteristics and sexual risky behaviors [16]; ethnic group, and practical knowledge of contraceptive methods, precociousness of the first sexual intercourse and early motherhood risky behaviors [17]; social representation, parental educational practices and risky behavior among adolescents [18].

Coming back to the link between self-esteem and risky behaviors, note that self-esteem refers to judgment or the assessment of an individual in relation to his own values. It transpires from this that when a person performs a valuable thing he thinks, feels an increased value and when evaluating his actions as being in opposition to his values he reacts as "bringing down in his esteem." Thus, a strong self-esteem may involve characteristics such as firm belief in his words and principles, the ability to make choices that seem right, self-confidence, positive anticipation of the future, resistance against manipulation. However a low self -esteem can convey important characteristics such as self-criticism, chronic indecisiveness, guilt, irritability, pessimism.

A number of studies have been conducted within this framework by researchers such as Smart and Boden [19] that show a correlation between high self-esteem and acts of violence or attack in case of threat or harm to the "ego"; Woo and Twinn [20] that demonstrate a significant effect of selfesteem on the phenomenon of early motherhood.

Other studies have also demonstrated the role of selfesteem in the development of risky driving behaviors. It shows that the high degree of self-esteem induce more risky driving behaviors [8].

Regarding the time issue, that is to say, how long someone lives on the streets, Kouadja [21]that this increases marginality, exclusion and risk: the longer the child's stay on the streets is, the more crime is committed. Kiénon [22] established a link between unemployment duration and the frustration feeling among the unemployed. He has shown in this study that the longer the unemployment duration lengthens, the more the unemployed has a feeling of intense frustration.

From all above, let us remember that self-esteem and the duration on the street can significantly influence the behavior of the individual especially in risk taking, as confirmed by many studies. However, few studies have been devoted to risky behaviors among adolescents of the street in our context in terms of self-esteem and the duration in the street. Our research aims to highlight the role of Self-Esteem and Length of Stay on the streets in the development of social marginality risky behaviors among adolescents of the street. From this, derives two hypotheses of work:

Hypothesis 1: "adolescents of the street" who have high self-esteem are more likely to engage in social marginality risky behaviors compared to their counterparts whose level of self-esteem is low.

Hypothesis 2: the more the length of stay on the street of the teenager is high, the more he develops social marginality risky behaviors compared to his counterparts whose life on the street is short.

\section{Methodological Approach}

\subsection{Description of Variables}

This research has two independent variables:

1- Self-esteem (of quantitative nature, based on the score of self-esteem). 2- Length of stay on the streets (of categoryspecific nature).

The dependent variable (of quantitative nature) is the risky behaviors of social marginality of the teenagers of the street. Details are given in the section data analysis method (preliminary analyses).

\subsection{Participants, Material and Survey Method}

Participants were 83 male street teenagers (aged 15 to 19 years old, $M=17.5$ ) who were randomly selected from a population of 216 children that are enrolled at "Centre Espoir BICE" (BICE Center of Hope) and "Case de l'Enfant de Children of Africa) ("The Child's Cabin of Children of Africa), two NGOs that provide shelter, food, and education to children on the streets in need of help. They were all residents of the District of Abidjan, the capitol city of Côte d'Ivoire, a West-African francophone country).

\section{Material.}

Participants completed a questionnaire which comprised 3 sections. The first section included sociodemographic questions that served to construct the status of the teenager as child on the streets. The questions were about the duration of time spent on the streets, place of residence, how they manage to feed themselves, the current state of contacts with their families (e.g., whether they see parents, brothers and sisters, or relatives, etc.), how they make money for living, their educational level.

The second section of the questionnaire assessed participants' self-esteem. Rosenberg's self-esteem scale was 
used. This consisted of 10 statements ranked on a scale of 1 to $4(1=$ absolutely in disagreement, never and $4=$ absolutely in agreement). The last section assessed participants' involvement in risky behaviors. This part of the questionnaire comprised 7 questions (e.g., "Do you drink only soft beverages, or alcoholic drinks sometimes"? "Do you sometimes sniff glue when you are hungry, but have no food"? "Do you share with friends stolen things?" "Do you fight with friends when you feel provoked"?).

\subsection{Data Analysis Method}

\section{Preliminary Analyses}

Self-esteem scores were calculated according to the criteria provided by Rosenberg [23]. The scores ranged between 8 and 40, lower scores corresponding to low selfesteem, and higher scores to high self-esteem $(M=20.82$; $\mathrm{SD}=11.50$ ).

Duration of stay on the streets was expressed in months. This varied between 0 to 6 months. Three levels of stay duration were determined based on the number of months declared: 0--2 months corresponded to low duration, 3--4 months to moderate duration and 5--6 months to long duration.

Finally, to determine participants' level of involvement in risky behaviors, a Yes answer was scored 2 and a No answer was scored 1. Thus, the total score that could be obtained varied between 7 and 14, with lower score meaning low involvement and higher scores high involvement in risky behaviors.

\section{Regression Analysis}

Next, a step by step multiple regression analysis was performed with self-esteem, length of stay on the streets as the predictors, and involvement in risky behavior as the criterion variable. Because it comprised 3 levels length of stay was subjected to dummy coding bringing the predictors to 4 .

\section{Presentation, Analysis and Interpretation of the Results}

\subsection{Self-Esteem and Length of Stay on the Streets}

As can be seen on Table 1, there is a positive and significant correlation between length of stay on the streets and involvement in risky behaviors, $\mathrm{r}(83)=.58, \mathrm{p}<.0001$, but a negative and significant correlation between selfesteem and involvement in risky behaviors, $\mathrm{r}(83)=-.79$, $\mathrm{p}$ $<.0001$. In other words, the longer the "adolescents of the street" stay on the streets, the more likely they are in getting involved in risky behaviors. In contrast, higher self-esteem seems to prevent from involving oneself in risky behaviors.

Table 1. Correlations among self-esteem, length of stay.

\begin{tabular}{|c|c|c|c|c|}
\hline & & Risky behaviors & Length of stay on the streets & Self esteem \\
\hline \multirow[t]{3}{*}{ Pearson's correlation } & Risky behaviors & 1,000 &, 579 &,- 791 \\
\hline & Length of stay on the streets &, 579 & 1,000 &,- 425 \\
\hline & Self-esteem &,- 791 &,- 425 & 1,000 \\
\hline \multirow[t]{3}{*}{ Signification (unilateral) } & Risky behaviors & &, 000 &, 000 \\
\hline & Length of stay on the streets & 000 & &, 000 \\
\hline & Self esteem &, 000 &, 000 & \\
\hline \multirow[t]{3}{*}{$\mathrm{N}$} & Risky behaviors & 83 & 83 & 83 \\
\hline & Length of stay on the streets & 83 & 83 & 83 \\
\hline & Self esteem & 83 & 83 & 83 \\
\hline
\end{tabular}

\subsection{Effects of Self-Esteem, Length of Stay on the Streets on Risky Behavior}

Table 2. Regression of Involvement in Risky Behaviors on Self-Esteem, Length of Stay on the Streets.

\begin{tabular}{llll}
\hline Model & B & SE B & Beta \\
\hline 1 (constant) & 15,218 &, 416 & \\
Self-Esteem &,- 204 &, 018 &,- 791 \\
2 (constant) & 15,219 &, 380 & \\
Self-Esteem &,- 177 &, 017 &,- 688 \\
Short Length of Stay & $-1,766$ &, 424 &,- 278 \\
\hline
\end{tabular}

As can be seen on Table 2, the regression of involvement in risky behaviors on Self-esteem, Length of Stay on the Streets yielded two models. The first comprises self-esteem only, and was significant, $\mathrm{R}^{2}=-.63, \mathrm{~F}(1,81)=135, \mathrm{p}$ $<.0001$. The second model includes both self-esteem and length of stay on the streets, $\mathrm{R}^{2}=-.69, \mathrm{~F}(2,80)=89.78, \mathrm{p}$ $<.001$. However, self-esteem is the best predictor of involvement in risky behaviors accounting for $63 \%$ of the variance. In effect, adding short length of stay in the regression only brings a small change, the $\mathrm{R}^{2}$ raises to .69 , suggesting that short length of stay accounts for $6 \%$ of the variance. As a result, short length of stay was excluded leaving a single model with self-esteem as the main predictor. In sum, these results suggest that high self-esteem adolescents are less likely to get involved in risky behaviors.

\section{Discussion}

The objective of this study was to examine the extent to which self-esteem and the duration of stay on the streets affect the involvement of adolescents living in the streets in risky behaviors. The results partially support the hypotheses. One, a positive between duration of the stay on the streets and involvement in risky behaviors. At first glance, this hypothesis was confirmed, a positive and significant correlation was obtained between the two variables. Second, 
a positive relation was predicted between self-esteem and involvement in risky behaviors, such that higher self-esteem would be related to higher involvement in risky behaviors. The findings contradicted this prediction. Self-esteem was negatively related to involvement in risky behaviors.

Further, when involvement in risky behaviors was regressed on self-esteem and duration of stay on the streets, with a dummy coding duration, the results showed a different pattern. Only self-esteem accounted for the street adolescents' involvement in risky behaviors. Duration of stay on the streets, especially short duration stay, very weakly accounted for this behavior. Clearly, higher self-esteem prevents adolescents from a getting involved in risky behaviors.

These present results contradict the previous findings. In a study on risky driving behaviors, Otémé [9] highlights the effect of self-esteem on risky driving behaviors (e.g., exceeding the speed limit, bad overtaking) finding that these increase with higher self-esteem: Similarly Baumeister, Smart and Boden [19], highlight self-esteem as a factor which affects risk taking among adolescents: those with high self-esteem engage in most aggression and violence in response to threats or an attack on the "ego". Crocker et al. [24] note, moreover, that the self-positive evaluations are linked to a certain number of behaviors that can be seen as defensive and potentially poorly adapted such as prejudice, aggressive, violent behaviors (Baumeister $\&$ al. [25]. These studies are inconsistent with our findings: highly positive self-evaluations are more likely to prevent subjects from risky behaviors (e.g., fighting, alcohol and drug abuse).

The present results also show a positive and significant relationship of between the duration of the stay on the streets on risky behaviors. This seems to support the work of Kouadja [21] on juvenile delinquency among street children, which showed that the longer the child's stay in the street the higher the involvement in delinquent acts: theft, alcohol, drug abuse, etc.... However, a closer look at the present results suggests, contrary to Kouadja's, that the relationship between duration of stay on the streets and involvement in risky behaviors is rather trivial.

\section{Conclusion}

This study allowed us to see the extent to which both selfesteem and the duration of the stay on the streets affect the involvement of street adolescents in risky behaviors. The findings were inconsistent with what previous studies that investigated similar variables lead to expect. It was observed that only self-esteem, but not duration of stay on the streets can account for the likelihood that the street adolescents would involve themselves in risky behaviors. The present finding thus raises some questions as to whether self-esteem can both facilitate and prevent risky, or marginal behaviors. A first answer can be derived from how the relation between self-esteem and the relevant behaviors has been assessed. Possibly, the contradiction between the present findings and previous ones (e.g., Otémé [9], Kouadja [21]...) may be due to the fact that some authors only relied on correlations or contingency tables (khi-squares), but not on regression analyses. Another answer may be that self-esteem may not be universally related to specific kinds of behaviors, be they positive or negative, desirable or undesirable.

Nevertheless, a lesson that can be learned from the present study is that strategies and policies intended to reduce street children's involvement in risky behaviors should take into account the self-esteem of these children.

\section{References}

[1] Marion, S. (2013). Les enfants en situation de rue à Katmandou: étude comparative de la représentation sociale de la vie dans la rue des enfants en situation de rue et des travailleurs sociaux Népalais. Mémoire de master de psychologie. Université Toulouse.

[2] Kalau-Mutaej, J-M, Malonga, kaj, F. (2013). Etude des déterminants socio-familiaux associés aux comportements sexuels à risque des adolescents de Lumbashi. Thèse, HALL, Archivres. Ouvertes. Fr.

[3] Jassor, R. (1987). Risky driving and adolescent Problem Behavior: An extension of Problem-Behavior Theory. ALCOHOL, DRUG and DRIVING. Vol. 3, nº 3-4, P. 1-11.

[4] Gherghel, A. (2005). La Monoparentalité en Roumanie, Marginalité sociale ou modèle, Université Laval.

[5] Koudou O. (1994). Communication: Les familles africaines: Des textes à leur représentation mentale chez les enfants et adolescents inadaptés sociaux. Annales des Lettres, Arts et Sciences Humaines. Université Nationale de Côte d'Ivoire, Num spécial: Colloque international sur textes et images dans production littéraire africaine, P. 51-58.

[6] Assailly, J-P. (2001). Les conduites à risque: du danger à la loi; des gènes aux pairs. Revue toxicobase; 11; 1-14.

[7] Bellavance, F., Dassa, C., Gou, M., Bellavigna-Ladoux, O., Messier, S. (2003). Les nouveaux conducteurs: Profils, prise de risque, évaluation des compétences et tests. CRT. http://www.crt.umontreal.ca/programation/detailprojet.php.uid. 16 juin 2015

[8] Lips, R. (2013). Les conduites à risque chez les adolescents: le cas de la scarification. Mémoire de master de psychologie. IUFM de Villeneuve.

[9] Otémé, A. C. (2010). Les chauffeurs des taxis communaux et les accidents de la circulation dans le district d'Abidjan: aspiration au projet professionnel, estime de soi et comportements à risque. Revue ivoirienne d'anthropologie et de sociologie, $n^{0} 18-2010,81-96$. EDUCI.

[10] Parazelli, M. (2000). L'imaginaire familialiste et l'intervention sociale auprès des jeunes de la rue: une piste d'intervention collective à Montréal. Santé mental au Québec, vol. 25, $\mathrm{n}^{\circ} 2$, 2000, p. 40-66.

[11] Douville, O. (2004). Enfants et adolescents en danger dans la rue à Bamako (Mali): questions cliniques et anthropologiques à partir d'une pratique. Psychopathologie africaine, XXXII, 1 .

[12] Vanistendael, S. (1992). Les enfants de la rue: problème ou personne? Genève: BICE. 
[13] Fischoff, B., Lichtenstein, S., Slovic, P., Derbi, S. L. \& Keeney, R. L., (1981). Acceptable risk. Cambridge: Cambridge University Press. 189P.

[14] Leplat, J. (2006). LEPLAT, J. (2006). Risque et perception du risque dans l'activité. In D. R. Kouabenan, B. Cadet, D. Hermand \& M. T. Muñoz Sastre (Eds.), Psychologie du risque, Bruxelles: De Boeck, pp. 21-33.

[15] Dogbe, L. M. (1994). Alcoolisation et marginalisation sociale chez le retraité ivoirien. Mémoire de maitrise de psychologie. Université Nationale de Côte d'Ivoire. Inédit.

[16] Mburano (2000). Sexual Risk Behaviors among Young People in Bamenda, Cameroon, International Family Planning Perspectives. Vol. 26, No. 3, pp. 118-123+130.

[17] Djoumetio, N. S. (2010). Pauvreté et grossesse des adolescents. Mémoire professionnel. Cameroun, institut national de la statistique.

[18] Pourtois, J-P \& Desmet, H. (1989). L'éducation familiale; Revue française de pédagogie No. 86, pp. 69-101.

[19] Baumeister, R. S, Boden, L., Smart, J. M. (1996). « Relation of treatened egotism to violence and agression: the dark side of high self-esteem », Psychological Review, n ${ }^{\circ} 64$.

[20] Woo, H. \& Twinn, S. (2004). Health needs of Hong Kong Chinese pregnant adolescents. Journal of Advanced Nursing, 45 (6), 595-602.

[21] Kouadja, A. (1996). Les enfants de la rue et la délinquance juvénile: le cas d'Abidjan. Mémoire de maitrise de psychologie. Université Nationale de Côte d'Ivoire, Inédit.

[22] Kienon, J. (1995). Durée de chômage, catégorie socioprofessionnelle et sentiment de frustration sociale chez le compressé. Mémoire de maitrise de psychologie. Côte d'Ivoire, Université Félix Houphouët-Boigny (Abidjan).

[23] Valieres, E. F \& Vallerand, R. J. (1990). Traduction et validation Canadienne-Française de l'Echelle de l'Estime de Soi de Rosenberg. International Journal of Psychology; Vol. 25, Issue 2, P. 305-316. First published online: 27 Sep. 2007.

[24] Crocker, J., Thompson, L. L., McCraw, K. M., Ingerman, C. (1987). "Downward comparison, prejudice, and evaluations of others. Effects of self-esteem and threat", journal of personality and social psychology, $\mathrm{n}^{\circ} 52$. 